\title{
Kitap Değerlendirmesi: Levin, D., Podmore, S. D. ve Williams, D. Mystical Theology and Continental Philosophy: Interchange in the Wake of God. (London: Routledge, 2017), s. 275.
} ISBN-13: 978-0367881788

\section{Recep AlpyağıI ${ }^{*}$ (1)}

Bugün, özellikle Kıta Avrupası felsefesi veya kısaca Kitasal felsefe (Continental philosophy) olarak adlandıran bağlamda mistik olanın "geri dönüşü” denebilecek bir atmosfer var. Bu durumu, sadece son 10 yıl içerisinde bu sahada yayınlanan akademik metinlerin sayısındaki muazzam artıştan görebiliyoruz. "Geri dönüş” ifadesinin de çağrıştırdığı üzere, bir süredir Kıtasal felsefe kendisini "ilahi olan”a, "mistik olan”a kapatmış durumdaydı. Bu metinde tanıtımını yapacağımız kitap da, tam olarak başlığında işaret edilen türden bir uyanışı kendisine konu edinmiş.

Mystical Theology and Continental Philosophy adlı eser çok farklı sahalardan akademisyenlerin katkısıyla oluşmuş disiplinlerarası bir çalışma. Editörlerin ifadesine göre 2014 yılında yapılan bir sempozyumun kitaplaşmış hali. (Mystical Theology and Continental Philosophy: Historical and Contemporary Perspectives, Liverpool Hope University, $11^{\text {th }}-13^{\text {th }}$ July, 2014) Bu çalışmadaki metinler, mistik teoloji ve Kitasal felsefe ilişkisini 4 ana tema üzerinden ele alıyorlar: 1. Post/modern bir bağlamda mistik geleneğin alımlanış1. 2. Negatif teoloji ve Kitasal felsefe. 3. Alman mistik Meister Eckhart ve Heidegger bağlantısı. 4. Yeniden okumalar ve yeni sınırlar.

1. Konuyu takip edenlerin bildiği üzere, Kitasal felsefenin ana kavramları olan "metinlerarasılık, ufukların kaynaşması, diyalojik düşünme, kolaj, kiyazma, jeo-felsefe, izlerin oyunu, dekonstrüksiyon, çeviri etkinliği vb." ihmal edilen gelen-ek-lerle çok farklı türden ilişkilerin önünü açmaktadır. Bu anlamda klasik olanla modern olanın birlikteliğine

\footnotetext{
* Sorumlu Yazar: Recep Alyağıl (Prof. Dr.), İstanbul Üniversitesi, İlahiyat Fakültesi, Felsefe ve Din Bilimleri Bölümü, İstanbul, Türkiye. E-posta: recepalp@istanbul.edu.tr ORCID: 0000-0003-3653-1842 
imkan vermektedir. Dahası bizatihi mistik gelen-ek-lerin dinamik doğası da bu türden yeniden, ve yeniden okumaları fazlasıyla mümkün kılmaktadır.

2. Derlemenin ikinci bölümündeki metinler mistik teolojinin metodik dilini kendine konu edinmiş: Apohasis. Apofatik teoloji, "olumsuz yol" (via negativa) gibi adlarla da anılan negatif teoloji, Tanrı'nın mahiyetini, onun ne olduğundan çok ne olmadığı ile anlatmayı tercih eder. Bu bölümdeki yazarlar negatif teolojide “insanın sınırlılı̆̆ı ve bunun devamında dilin Tanrı'yı konuşmada ve anlamada olan yetersizliği vb. gibi” temaların post-modern bağlamdaki “öznenin ölümü, yeni bir özenin doğuşu vb. gibi” tartışmaları aydınlatabileceği fikri üzerinde duruyorlar. Bu anlamda, negatif teoloji dendiğinde akla ilk gelen felsefecilerden olan J. Derrida da ana isim olarak görünüyor.

3. Üçüncü bölümdeki metinler ise tamamen Meister Eckhart ve M. Heidegger bağına ayrılmış durumda. Eckhart'ın, Heidegger'in gençlik dönemi eserlerinden olgunluk dönemi metinlerine dek izi sürülüyor. Vakıa Kıtasal felsefede bu ölçüde etkili olan bir düşünürün mistik kökleri olması konuyu ilginç kılıyor. Ayrıca bu iki alan arasındaki geçişlerin felsefi meşruiyetini de sunuyor. Bu anlamda Heidegger' in en temel kavramsallaştırmalarından birisi onto-teo-lojidir. Ayrı bir çalışmayı hak edecek kadar yaygın bir kullanım alanına sahip olan onto-teo-loji tabiri şunu ima eder: "Salt felsefi kategoriler Tanrıyı anlamak için yetersizdir. Herhangi bir kavram onu çerçeveleyemez. Tanrı varlığı ve varolmamayı aşandır". Bu perspektif doğal olarak mistik teolojiye, özellikle de Eckhart’ta örneği görülen bir teolojiye kap1 aralıyor.

4. Son bölümde Kitasal felsefede "mistik teoloji"ye görece olarak daha uzak görünen felsefeciler konu edinilmiş: G. Deleuze ve S. Zizek. Özellikle de Deleuze yeni öznellik, metinsellik, yazım, düşünce ve politika tarzları geliştirme çabası içinde olmuştur. Bu anlamda o, klasik felsefe içinde şekillenen özdeşlik, temelcilik, özne vb. kavramları yerinden etmeye dönük bir eleştiriyi temsil eder. Deleuze’ün felsefesindeki çoklu katmanlar içinde veya arasında derin bir evetleme, mistiklere benzer olumlayıcı bir yöne vurgu yapılıyor derlemede. Deleuze'ü, farklı oluşlar, farklı öznellikler peşinde olan bir filozof olarak okumak daha anlamlı görünüyor. Bu açıdan, bu oluşlar dizisine bir yenisini eklemek pekala mümkün: Mistik oluş.

Son tahlilde bu çalışmayı yine kendi dili ile değerlendirecek olursak, yani negatif teolojinin hem olumlayan hem de olumsuzlayan çifte dili ile, şunları söylemek mümkün: Müspet olan yön, -metin içinde de anlattı̆̆ımız üzere- bu derleme kuşkusuz sahaya ilişkin oldukça önemli bir katkı sunuyor. Menfi olan yön ise her ne kadar derlemede "Yeniden okumalar ve yeni sınırlar"dan söz edilse de bu sınırların ve yeniden okumaların Avrupa merkezci kaldığını söylemek mümkün. 
Yani faklı bağlamlardaki mistik teolojilere neredeyse hiç atıf yok. Bu anlamda negatif teolojinin imkânları yeterince kullanılmamış görünüyor.

Bu derlemenin, Türkçedeki Kıtasal felsefe çalışmalarına dönük de imaları olabileceğini düşünmekteyiz. Şöyle ki Türkçede Kıta Avrupası felsefesi üzerine yapılan çalışmalarda önemli bir birikim olmasına rağmen, konunun burada sunulan yönü -mistik teoloji- neredeyse hiç ele alınmamıştır. Aksine olarak, Kıtasal felsefe ülkemizde daha ziyade din karşıtı bir bağlamda okunuyor görünmektedir. Öyle zannediyoruz ki derlemenin eksik bıraktığı yön ile Türkçede eksik kalan yön üzerinde çalışılması halinde, ülkemizdeki felsefe faaliyetleri çok derinlikli bir açılım kazanabilir. Derleme ayrıca, İlahiyat Fakültelerindeki Analitik felsefe ağırlıklı din felsefesi çalışmalarına yeni bir problem alanı sunuyor. 
